\title{
Body size and colour-pattern genetics in the polymorphic mimetic butterfly Hypolimnas misippus (L.)
}

\author{
IAN J . GORDON $†$ \& DAVID A. S. SMITH* \\ $\dagger$ Kipepeo Project, Box 57, Kilifi, Kenya and †Natural History Museum, Eton College, Windsor, Berkshire SL4 6EW, \\ U.K.
}

\begin{abstract}
The diadem butterfly, Hypolimnas misippus, shows various anomalies in its presumed Batesian mimetic relationship with the distasteful danaine, Danaus chrysippus. If these anomalies are to be resolved and if reports of sexual selection in female diadems are to be correctly interpreted, an understanding of the genetics of the colour pattern polymorphism is essential. In an earlier study we developed a three-locus model (the $A-M-S$ model) for colour pattern genetics in the diadem butterfly. Here, we show that the $A$ locus segregates for body size as well as colour pattern. It is probably a supergene with at least four loci linked in coupling. Segregation for body size confirms several aspects of the $A-M-S$ model: the ability of different genotypes to produce the same mimetic phenotype; the presence of a suppressor allele for hindwing white; and the effects of the $A$ locus on the forewings of $\mathrm{mm}$ butterflies. Differences between the genetics of colour pattern in H. misippus and its model, D. chrysippus, favour a multiple origins rather than a selective maintenance hypothesis for the evolution of mimicry. Body size differences in both sexes must play a significant but as yet unexamined role in the maintenance of colour pattern polymorphism and in sexual selection in this species.
\end{abstract}

Keywords: body size, genetics, Hypolimnas misippus, mimicry, sexual selection.

\section{Introduction}

The diadem butterfly, Hypolimnas misippus, has long been a puzzle to students of Batesian mimicry, because detailed resemblances to four different colour pattern morphs of its presumed model, Danaus chrysippus, seem, from the geographical distribution of matching forms, to provide no protective advantage (Owen \& Chanter, 1968; Bernardi, 1974; Smith, 1976; Pierre, 1980). Previous discussions of this paradoxical situation, in which mimics are found thousands of miles outside the range of their supposed models, have been hampered by ignorance of the genetics of colour pattern in H. misippus. This ignorance has also weakened attempts to interpret sexual selection in this species, the existence of which is suggested by intriguing and contradictory evidence from three independent investigations (Stride, 1956, 1957; Unamba, 1968; Edmunds, 1969a,b). Although Smith (1984) reviewed this evidence in the light of what was then known

\footnotetext{
*Correspondence. E-mail: dass@etonscil.co.uk
}

about the genetic control of colour pattern, the genetic model used was incomplete.

In two earlier papers (Smith \& Gordon, 1987; Gordon \& Smith, 1989), we developed a model for the inheritance of colour pattern in H. misippus which involves three unlinked autosomal loci. These loci exhibit hierarchical epistasis, a feature which we suggested may be a major evolutionary alternative to the supergene as a means of controlling the joint expression of different but functionally related genes in a polymorphic system. In this paper, we present new data on an association between body size (forewing length) and colour pattern which confirms and extends our model. This association, in which the presence of the allele for white hindwings is linked with reduced body size, allows us to demonstrate the presence of a suppressor gene whose existence we had previously inferred only from segregation data. Occasional breakdown in the association between pattern and size also suggests that a supergene may, after all, be present. We discuss our findings in the light of our proposed model, the mimetic anomalies noted above, and a 
possible reinterpretation of the data on sexual selection.

\section{Phenotypes and genotypes}

The Latin names given to the four commonly recognized forms (misippus, inaria, alcippoides, and inariaalcippoides) conceal the fact that there is a continuum in colour pattern between them (see illustrations in Gordon, 1987; Smith \& Gordon, 1987). Edmunds (1969a) devised a codified description for this continuum which we have found to work well and have used in our genetic and field studies. The forewing code specifies the colour of the forewing apex ( $b l$ for black, $b r$ for brown, and $o$ for orange) and that of the subapical band ( $w$ for white, $p$ for pale orange, $o$ for full orange). There are thus nine complete forewing codes (blw, blp, blo, brw, brp, bro, ow, op and oo) of which two (blp and blo) have not been observed. The hindwing code specifies the amount of white in the otherwise orange hindwing and ranges from 0 to 10 , the number specifying the number of interveinular spaces with white scales present. Scores of more than 8 for hindwing white are extremely rare. Altogether there is a total of 99 possible fore- and hindwing combinations of which fewer than half are commonly encountered in the field. We have made one addition to Edmunds's system, the prefix $M$ denoting rare melanic female forms.

Table 1 shows how the various code classes (excluding melanics) relate to the Latin names for the different forms and to our genetic model. In addition to the four commonly used names listed above, we adopt the name immima, first proposed by Bernardi (1959), because this is a recognizable genotype $(A-)$ at the major locus controlling hindwing colour and it serves as an inclusive category for the intermediate, nonmimetic forewings. We also subdivide the alcippoides classes (into strong and weak) according to the amount of white in the hindwing, again for genetic reasons and because the

Table 1 Colour pattern phenotypes and genotypes in Hypolimnas misippus (based on Gordon \& Smith, 1989)

\begin{tabular}{lll}
\hline $\begin{array}{l}\text { Phenotypes } \\
\text { code }\end{array}$ & Name & Genotypes \\
\hline blw0 & misippus & $M-/ A a /--, M-/ A-/ S S$ \\
blw1-3 & weak alcippoides & $M-/ A-/ S s$ \\
blw 4-10 & strong alcippoides & $M-/ A-/ \mathrm{ss}, \mathrm{mm} / A A / \mathrm{ss}$ \\
brw-op0 & immima & $\mathrm{mm} / A-/ \mathrm{SS}$ \\
brw-op1-10 & immima-alcippoides & $\mathrm{mm} / \mathrm{A}-/ \mathrm{Ss}, \mathrm{mm} / \mathrm{A}-/ \mathrm{ss}$ \\
oo0 & inaria & $\mathrm{mm} / \mathrm{aa} /-$ \\
\hline
\end{tabular}

quantity of white often determines the quality of mimicry. We use italics for the Latin names only when referring to the phenotype combinations identified in the table; for example misippus refers to blw0 forms, whereas misippus refers only to blw forewings.

Three interacting loci are identified in Table 1: the $M, A$ and $S$ loci. The $M$ locus controls forewing colour with $M-$ giving the misippus (blw) pattern and $\mathrm{mm}$ giving inaria (oo) or immima (brw, brp, bro, $o w$ and $o p$ ) patterns. The dominance of $M$ over $m$ is complete, so that all $M$ - butterflies have $b l w$ forewings. The forewing phenotype of $\mathrm{mm}$ butterflies is largely determined by the $A$ locus, being inaria in $m m / a a$, immima in most $m m / A-$ and even misippus in some $m m / A A$ genotypes. The $A$ locus also determines the presence or absence of white in the hindwing. In $a a$ butterflies, the hindwing is always completely orange, whereas in $A$ - butterflies it may be orange or have varying degrees of white depending on the genotype at the $S$ locus. $A-/ s s$ butterflies always have a large white patch, scoring 4-10 in Edmunds's system, whereas $A-/ S$ - butterflies either have completely orange hindwings or a small white patch, scoring $0-3$. The dominant allele at the $S$ locus suppresses white in $A$ - butterflies, both in the hindwing and in the subapical band. The overall expression of hindwing white probably depends on an allelic balance at the $A$ and $S$ loci with $A a / S S$ butterflies scoring 0 , whereas $A A / S s$ butterflies score 2-3 or (rarely) more. $S$ also suppresses white in the subapical band of the forewing in $m m / A$ - butterflies, although it has no effect on the apical colour (Gordon \& Smith, 1989).

It should be noted that there is one combination of fore- and hindwing phenotypes that is absent from Table 1, although it has been recorded from the field (see below). This is inaria-alcippoides (oo1-10), and it is omitted from the table because it should not exist according to our original genetic model (Gordon \& Smith, 1989). We discuss the inheritance of this form below. We also omit the melanic forms (which are probably controlled by a fourth locus) as they are extremely rare in natural populations.

\section{Methods}

Our breeding methods have been described elsewhere (Smith \& Gordon, 1987; Gordon \& Smith, 1989). The additional data described here came from wild butterflies which were captured during extensive mark-recapture studies between 1974 and 1979 at Cape Coast in Ghana. Each butterfly was

(C) The Genetical Society of Great Britain, Heredity, 80, 62-69. 
given an individual mark and its forewing length was measured and recorded to the nearest millimetre using a hand-held ruler.

\section{Results}

Figure 1 shows the frequency distributions for the forewing lengths of males and the major female phenotype classes. Visual inspection of the histogram (Fig. 1a) for the large sample of misippus $(n=524)$ suggests that it is bimodal; graphical analysis on arithmetical probability paper using the method of Harding (1949) confirms that this is so. There are two overlapping frequency distributions with means $\pm \mathrm{SD}$ of $37.0 \pm 1.8 \mathrm{~mm}$ and $42.8 \pm$

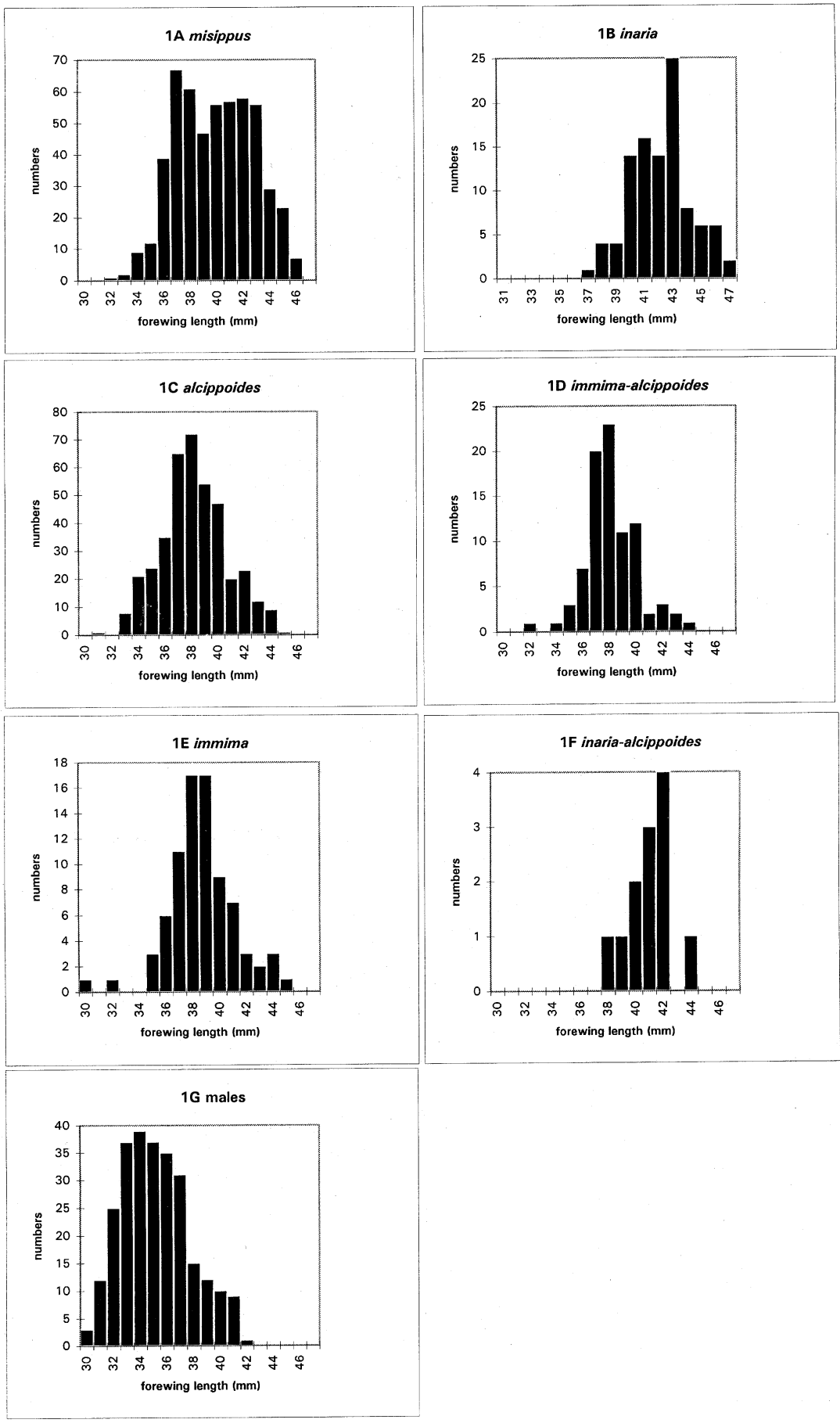

Fig. 1 Forewing length frequency distributions in different colour pattern forms of Hypolimnas misippus. 
$1.6 \mathrm{~mm}$, respectively, the sample dividing into two approximately equal fractions. The other female classes analysed in the same way are unimodal and fall into two groups, each of which matches one or other of the two modes for misippus. The two groups differ significantly $(d=16.5, P<0.001)$. The alcippoides, immima and immima-alcippoides classes (Fig. 1c,e) are formally homogeneous with an overall mean of $38.3 \pm 2.5 \mathrm{~mm}(n=561)$, whereas inaria and inaria-alcippoides (Fig. 1b,f) form a second homogeneous group with an overall mean of $42.2 \pm 2.1 \mathrm{~mm}(n=111)$. There are thus two distinct size-groups, each of which comprises several different phenotypes and which both include misippus.

A null hypothesis that the size-frequency distributions of the female morphs strong alcippoides, weak alcippoides, immima, immima-alcippoides and inaria (Table 2) are normal is not rejected $(P>0.05)$ by $\chi^{2}$-tests for goodness of fit; in contrast the postulated bimodal class misippus rejects normality $\left(\chi_{13}^{2}=66.0\right.$, $P<0.001)$, as expected. A Tukey test analysis (Table 2) shows that the two size groups are internally homogeneous with respect to mean forewing length and are significantly different from one another. The misippus forms are excluded from the tests of significance as population parameters derived graphically are not strictly comparable to those obtained by computation.

The frequency histogram (Fig. 1g) for the males, which are smaller, is flat-topped, and rejects normality $\left(\chi_{10}^{2}=37.3, P<0.001\right)$, suggesting that they may also be bimodal for body size. Graphical analysis using Harding's method again permits the clear separation of two overlapping normally distributed components with mean forewing lengths and standard deviations of $33.7 \pm 1.8 \mathrm{~mm}(n=200)$ and $39.0 \pm 1.9 \mathrm{~mm}(n=66)$. The difference between the means is highly significant $(d=19.91, P<0.001)$. Interestingly, the proportions of small and large males ( $\approx 75$ per cent and 25 per cent, respectively) are not significantly different from those of small and large females $(69$ per cent and 31 per cent, $n=1194)\left(\chi_{1}^{2}=3.77\right)$.

\section{Discussion}

\section{Body size and the A-M-S model}

The results show that the $A$ allele for white hindwings is associated with small size and $a$ with large size in females and suggest that the same may be true for males. Small size is dominant and is not subject to suppression by $S$. In our original discussion of the $A-M-S$ model (Gordon \& Smith, 1989) we noted that inheritance of hindwing colour in H. misippus was complex and that hypotheses other than those we had examined were possible. The findings discussed here have considerably increased our confidence in the $A-M-S$ model. Not only have several of its key features been confirmed, but it has demonstrated a capacity to absorb and explain new data.

First, the bimodal distribution for forewing length found only in misippus butterflies confirms that this colour pattern can be produced by different genotypes. If the $A$ locus segregates for body size as well as for colour pattern, then two modes are predicted in this form (and only in this form) because we expect blw0 forms in both $M-|A-| S-$ and $M-/ a a /$ - - genotypes. Secondly, bimodality for forewing

Table 2 Tukey test analysis of forewing length (fwl) data for female phenotype classes (excluding misippus)

\begin{tabular}{|c|c|c|c|c|c|c|}
\hline $\begin{array}{l}\text { Mean fwl }(\mathrm{mm}) \\
\text { Phenotypes }\end{array}$ & $\begin{array}{c}37.9 \\
\text { str. alc. }\end{array}$ & $\begin{array}{c}38.2 \\
\text { im.-alc. }\end{array}$ & $\begin{array}{c}38.4 \\
\text { weak alc. }\end{array}$ & $\begin{array}{l}38.7 \\
\text { imm. }\end{array}$ & $\begin{array}{c}41.0 \\
\text { in.-alc. }\end{array}$ & $\begin{array}{c}42.2 \\
\text { in. }\end{array}$ \\
\hline$N$ & 123 & 89 & 269 & 81 & 11 & 100 \\
\hline str. alc. & - & NS & NS & NS & $*$ & $*$ \\
\hline im.-alc. & 1.31 & - & NS & NS & $*$ & $*$ \\
\hline weak alc. & 2.66 & 0.86 & - & NS & $*$ & $*$ \\
\hline$i m$ & 3.45 & 1.99 & 1.60 & - & $*$ & $*$ \\
\hline in.-alc. & 5.91 & 5.23 & 5.10 & 4.26 & - & NS \\
\hline in. & 18.45 & 16.09 & 19.30 & 13.77 & 2.18 & - \\
\hline
\end{tabular}

$F_{5,684}=40.31, P<0.001$. Lines below phenotype classes in the column headings indicate the two separate size groups. Figures below the diagonals give the $q$-values for each comparison, and their significance is shown above the diagonal by NS (not significant) and * (significant) $\left(q_{[0.05,120,6]}=4.10\right)$. 
length in misippus provides strong support for the existence of a gene which suppresses white in the hindwing. The modal group $(M-/ A-/ S-)$ with small wings must be carrying the dominant allele for white hindwings and yet their hindwings are orange. Thirdly, the fact that inaria are large, whereas immima, immima-alcippoides and alcippoides are small, shows the presence of the dominant $A$ allele in the latter three forms and its absence in the former, and thus demonstrates that this allele converts inaria wings into immima wings. This confirms in detail the genetic association we postulate between white hindwings and intermediate forewings (Gordon \& Smith, 1989). In particular we can be confident that all inaria are $\mathrm{mm} / \mathrm{aa} / \mathrm{-}_{-}$, all mm/aa/- - are inaria, and that all immima are $m m / A-/ S-$.

However, the forewing length data raise an important question concerning the nature of the $A$ locus: is it a supergene? There are at least four phenotypic characters associated with this locus: apical colour, colour of subapical band, hindwing colour and body size. Two of these, colour of subapical band and hindwing colour, are subject to suppression by $S$, but the other two are not. One (body size) is expressed in males but the other three are not. There is also the complication of variable penetrance: there is complete dominance for small body size and for hindwing white in the absence of $S$, but not for colour of apex or subapical band. Is this complex range of effects and gene interactions traceable to a single pleiotropic locus or are several tightly linked loci involved?

We originally (Gordon \& Smith, 1989) favoured the former interpretation, suggesting that the $A$ locus was a regulatory switch gene controlling the expression of unidentified structural genes for foreand hindwing colour. However, the new data cast doubt on this conclusion. There are two major difficulties. First, it seems unlikely (although not impossible) that a single regulatory locus could control such disparate characters as wing colour and body size. Secondly, the fact that inaria-alcippoides forms (ool-8, $\mathrm{mm} / \mathrm{A}-1--)$ do exist and that they are all large (Fig. 1f) is strong evidence for a linkage hypothesis. As noted earlier, this colour form is excluded under our published genetic model, because the presence of the $A$ allele should convert the inaria forewing into immima forewings. Yet oo1-8 butterflies have been recorded in field samples, albeit rarely, by each of the three investigators who have used Edmunds's code in describing phenotypes (Edmunds, 1969a; Smith, 1976; Gordon, 1982; this paper).
The simplest explanation for the existence of this form and for the fact that it is always large (despite the manifest presence of the $A$ allele) is that it results from recombination within a supergene regulating forewing colour pattern, body size and hindwing colour pattern. Four loci could be involved: (i) $P$ with a semidominant allele for a black apex; (ii) $O$ with a semidominant allele for a white subapical band; (iii) $L$ with a dominant allele for small body size; and (iv) $A$ with a dominant allele for hindwing white. Coupling linkage between these loci, together with the effects of the $S$ locus, would then explain the colour pattern and body size associations that are usually observed, and recombination would explain the exceptions. In particular, large inariaalcippoides would be explained by crossing-over between the $A$ locus and the $P, O$ and $L$ loci, giving a complete genotype of $\mathrm{mm} /$ ppoollA-/ss. Most immima genotypes would then be $\mathrm{mm} / \mathrm{P}-\mathrm{O}-$ $L-A-/ S-$, most immima-alcippoides would be $\mathrm{mm} / \mathrm{P}-\mathrm{O}-\mathrm{L}-\mathrm{A}-\mathrm{ss}$, and inaria would be $\mathrm{mm} /$ ppoollaa/- - .

It is not possible to be certain of the order of the four linked loci, but the rarity of bro (with a frequency of 0.5 per cent in a Ghanaian sample of 2771 butterflies) and the total absence of blo and blp forewings indicates tight linkage in coupling between the $P$ and $O$ loci. Further, as the large inaria-alcippoides forms must result from crossing-over between $A$ and the other three genes, one of four possible arrangements is likely: POLA, APOL, LPOA or $A L P O$.

\section{Mimicry in Hypolimnas misippus}

Despite the remarkable resemblances between the four different matching forms of the two species, numerous authors have questioned the status of $H$. misippus as a Batesian mimic of D. chrysippus. Bernardi (1974) and Pierre (1980) believe that mimicry was not involved in the origin of the resemblances between these species, although they agree that it may have been involved in their selective maintenance. Others (Poulton, 1908; Marsh et al., 1977) have suggested that the relationship may be Müllerian rather than Batesian. The strongest evidence against a Batesian interpretation comes from the biogeographical mismatching of model and mimic colour pattern forms (Bernardi, 1974; Pierre, 1980), but there are additional problems, including the high frequencies of nonmimetic forms throughout Africa and the often discordant model-mimic ratios that exist, particularly in irruptions of the mimic during the early rains. On the other hand 
there is field evidence for intermittent selection for mimicry and for apostatic selection for rare forms, suggesting that $H$. misippus is, indeed, a Batesian mimic (Edmunds, 1969a; Smith, 1976; Gordon, 1987). Further arguments in favour of Batesian as opposed to Müllerian mimicry are presented in Clarke et al. $(1989,1995)$.

Controversially, Bernardi (1974) and Pierre (1980) regard the mimetic patterns of the female diadems as ancestral and the male pattern as derived. They suggest that the colour patterns of female H. misippus and D. chrysippus are homologous, dating back to a time of common ancestry or, at least, to a common genetic and developmental heritage in the control of wing colour patterns. They therefore deny that the resemblances evolved by selection for mimicry, while agreeing that such selection may subsequently have helped to maintain them. This position is reminiscent of the ideas of Punnett (1915) and Goldschmidt (1945), who maintained that mimetic patterns could be established by a single mutation which activated ancestral gene/ development pathways shared by both model and mimic.

Although the classic work of Clarke \& Sheppard (1963) on Papilio dardanus is usually understood as refuting the ideas of Punnett and Goldschmidt, by demonstrating the presence of modifier genes which improve mimicry, it does not in fact disprove the activation of shared, ancestral, epigenetic systems; only the instantaneous creation of perfect mimicry is jeopardized. As Turner (1983) notes 'The question about the uncovering of old lost developmental pathways is clearly a most important and interesting one ... that ... is yet to be taken up.' Brower (1996) speculates that the evolution of mimicry in Heliconius butterflies may be 'driven by ... regulatory switches, operating on a relatively homogeneous developmental genetic template.' There are obvious difficulties in applying this argument to more distantly related species such as H. misippus and D. chrysippus, but it is a testable hypothesis because it predicts identity or strong similarity in pigment chemistry and in the ontogeny and genetics of colour pattern in the two species.

No data are currently available on pigment chemistry or on colour pattern ontogeny, but we do now have a reasonable understanding of colourpattern genetics in both species. In D. chrysippus three loci control wing patterns (Smith, 1975): a dominant allele at the $C$ locus produces all-orange forewings, whereas the recessive gives blackand-white-tipped forewings; a dominant allele at the $B$ locus gives a brown ground colour and a recessive gives tawny; a dominant allele at the $A$ locus gives orange hindwings and a recessive gives white. The $B$ and $C$ loci are tightly linked.

The following differences between the two species in their colour pattern genetics are apparent: (i) identical patterns can be produced by several different genotypes in misippus but not in chrysippus; (ii) opposite dominance relationships exist for the $M$ and $A$ loci in misippus and the corresponding $C$ and $A$ loci in chrysippus; (iii) there is evidence for a supergene in misippus, controlling both fore- and hindwing patterns, whereas in chrysippus fore- and hindwing patterns are separately controlled by unlinked loci; (iv) shared colour patterns are femalelimited in misippus but not in chrysippus (although nonrandom segregation of colour pattern with sex does occur in some chrysippus populations: authors' personal observations); (v) male colour patterns are monomorphic and male-limited in misippus (although a rare dominant gene produces male-like [transvestite] females: Gordon \& Smith, 1989), whereas in chrysippus all patterns are shared between the sexes; (vi) there is a suppressor gene for hindwing white in misippus but not in chrysippus; and (vii) there is no ground colour locus in misippus corresponding to the $B$ locus in chrysippus. These several differences argue against the selective maintenance hypothesis of Pierre (1980) and Bernardi (1974).

An alternative view, more in accord with the genetic data, is that the shared patterns have multiple origins and they arose through selection for mimicry, but that other selective forces are now usually equally, if not more, important. The fact that the same mimetic colour patterns can be produced by different genotypes in $H$. misippus provides direct evidence for multiple origins under strong selection, and there is good field evidence (Edmunds, 1969a,b; Smith, 1976; Gordon, 1987) that strong selection for mimicry does occur, albeit only intermittently.

Furthermore, the association of colour pattern and size demonstrated in this paper illustrates the importance of other selective forces. Body size is a keystone variable in the genetic and phenotypic architecture of any species because it affects so many other traits (Stearns, 1992 and references therein). Within insect species, it is positively correlated with adult lifespan, competitive ability and fecundity and is negatively correlated with generation time (Horn, 1978; Southwood, 1981). Large body size is generally characteristic of $K$-selected and small with $r$-selected life history strategies, and there is some evidence that white-hind-winged forms may be favoured by $r$-selection (Smith, 1976). Body 
size differences are also likely to affect sexual selection in this species as discussed below. These differences may well be the strongest current influence on wing colour polymorphism dynamics in $H$. misippus today.

The evidence presented thus suggests that H. misippus exists in two genetically distinct ecotypes. The large ecotype is probably relatively $K$-selected and has two discrete morphs, misippus $(M-/ a a)$ and inaria $(\mathrm{mm} / \mathrm{aa})$. The small ecotype is an $r$-selected irruptive butterfly; it also has two principal morphs, misippus and alcippoides, which intergrade through the various heterozygous forms. Where, as in this case, there is within a species a stable, widespread and persistent pattern of bimodal distribution for body size, with clearly separated means, and where members of each size class are capable of normal growth and reproduction in a natural environment, then differential adaptation may explain the variation (Stearns, 1992). Wilbur (1977) gives examples of size bimodality and polymodality in six plant species (Asclepias) and four amphibians (Amblyostoma). Hypolimnas misippus is the first example of body size dimorphism of which we are aware in butterflies (excluding sex-related differences). Kaplan \& Cooper (1984) and McGinley et al. (1987) suggest a number of processes that could explain such variation, although convincing empirical demonstrations remain lacking.

\section{Sexual selection}

Stride (1956, 1957), working in Ghana, used cardboard models and dead females fitted with alcippus hindwings or hindwings painted white to evoke courtship responses in wild H. misippus males; he demonstrated an apparently inhibitory effect of white hindwings. He argued that this might explain the relative rarity of the alcippoides forms in West Africa (he actually believed they were absent) despite their advantage with respect to mimicry (all the D. chrysippus in this area being form alcippus, with white hindwings).

This attractive hypothesis has, however, since been disproved. Stride (1957) had shown that fertilized females avoid the attentions of courting males by a characteristic, quivering, ascending flight. Edmunds (1969a,b), by observing wild butterflies, found no significant difference in the frequency with which this response was exhibited by white and by orange-hindwinged females. Unamba (1968), working in Sierra Leone, subsequently showed, by dissecting females for spermatophores, that virgins were significantly more frequent in orange-hindwinged forms and that multiple mating was commoner in the alcippoides forms (Smith, 1984). It therefore seems that white-hindwinged female H. misippus mate sooner and more often, rather than later and more seldom.

The body size differences reported in this paper raise several questions in this context; for example, small misippus carry the (suppressed) $A$ allele for white hindwings: do they also mate sooner and more often than large misippus? There are likely to be asymmetries in the mating preferences of males and females. Small females may have shorter lives and may need to mate more quickly (although not more often). Males are presumably best off mating with large females (Gwynne, 1981) because of higher fecundity and less sperm competition (see below), and so should presumably prefer orange-hindwinged forms which mate less often. If the small orange females mate earlier than the large orange females, this could be interpreted as indicating that females, rather than males, are in control of mating decisions; the small females being less coy.

On the other hand, it may be that smaller females are less able to evade larger males that are intent on mating, particularly as they are weaker fliers (Edmunds, 1969a; Smith, 1976), and because hindwings are used as a shield in this species to block mating attempts by males (I. J. Gordon, personal observation) and they may be less effective in this when they are small. The fact that small white females are mated more often (Smith, 1984) favours this interpretation. If this is the case, then female choice is, at least partly, subordinate to male will; sexual selection for colour pattern is merely an incidental result of the associated differences in body size, and there are interesting consequences for the population genetics of the $A$ locus (heterozygote excess without heterozygote advantage).

The body size differences also raise the possibility that the $A$ allele suffers adverse sexual selection in the male sex. Larger male body size may lead to greater success in establishing and maintaining territories or to greater success in mating attempts. Further work on sexual selection in $H$. misippus must take account of the association between body size and colour pattern reported here.

\section{Acknowledgement}

We thank Dr G. S. Oxford whose comments on a draft manuscript have improved this paper.

\section{References}

BERNARDI, G. 1959. La variation géographique du polymorphisme chez les Hypolimnas du continent africain. Bull. de l'I.F.A.N., 21.

(C) The Genetical Society of Great Britain, Heredity, 80, 62-69. 
BERNARDI, G. 1974. Polymorphisme et mimétisme chez les Lépidoptères Rhopalocères. Mém. Soc. zool. Fr., 37, 129-168.

BROWER, A. V. Z. 1996. Parallel race formation and the evolution of mimicry in Heliconius butterflies: a phylogenetic hypothesis from mitochondrial DNA sequences. Evolution, 50, 195-221.

ClARKE, C. A. AND SHEPPARD, P. M. 1963. Interactions between major genes and polygenes in the determination of the mimetic patterns of Papilio dardanus. Evolution, 17, 404-413.

ClARKE, C. A., CLARKE, F. M. M., GORDON, I. J. AND MARSH, N. A. 1989. Rule-breaking mimics: palatability of the butterflies Hypolimnas bolina and Hypolimnas misippus, a sister species pair. Biol. J. Linn. Soc., 37, 359-365.

ClARKE, C. A., CLARKE, F. M. M. AND GORDON, I. J. 1995. Mimicry and other controversial topics in East African Lepidoptera. J. E. Afr. Nat. Hist., 84, 2-19.

EDMUNDS, M. 1969a. Polymorphism in the mimetic butterfly Hypolimnas misippus in Ghana. Heredity, 24, 281-302.

EDMUNDS, M. 1969b. Evidence for sexual selection in the mimetic butterfly Hypolimnas misippus in Ghana. Nature, 221, 448.

GOLDSCHMIDT, R. 1945. Mimetic polymorphism, a controversial chapter of Darwinism. Q. Rev. Biol., 20, 147-164, 205-230.

GORDon, I. J. 1982. The Biology of Danaus chrysippus L. (Lepidoptera: Danaidae) and its Mimics in Ghana. Ph.D. Thesis, University of Ghana, Legon.

GORDON, I. J. 1987. Natural selection for rare and mimetic colour pattern combinations in wild populations of the diadem butterfly, Hypolimnas misippus L. Biol. J. Linn. Soc., 31, 1-23.

GORDON, I. J. AND SMITH, D. A. S. 1989. Genetics of the mimetic African butterfly Hypolimnas misippus: hindwing polymorphism. Heredity, 63, 409-425.

GWYNNE, T. 1981. Sexual difference theory: Mormon crickets show role reversal in mate choice. Science, 213, 779-780.

HARDING, J. P. 1949. The use of probability paper for the graphical analysis of polymodal frequency distributions. J. Mar. Biol. Ass. U.K., 28, 141-153.

HORN, H. s. 1978. Optimal tactics of reproduction and lifehistory. In: Krebs, J. R. and Davies, N. B. (eds) Behavioural Ecology: An Evolutionary Approach, pp. 411-429. Blackwell Scientific Publications, Oxford.

KAPLAN, R. H. AND COOPER, w. s. 1984. The evolution of developmental plasticity in reproductive characteristics: an application of the 'adaptive coin-flipping principle'. Am. Nat., 123, 393-410.

McGinley, M. A., TEMME, D. H. AND GEBER, M. A. 1987. Parental investment in offspring in variable environments: theoretical and empirical considerations. Am. Nat., 130, 370-398.

MARSH, N. A., CLARKE, C. A., ROTHSCHILD, M. AND KELLET, D. N. 1977. Hypolimnas bolina (L.), a mimic of danaid butterflies, and its model Euploea core (Cram.) store cardioactive substances. Nature, 268, 726-728.

OWEN, D. F. AND CHANTER, D. O. 1968. Population biology of tropical African butterflies. 2 Sex ratio and polymorphism in Danaus chrysippus L. Rev. Zool. Bot. Afr., 78, 81-97.

PIERRE, J. 1980. Variation géographique du polymorphisme et du mimétisme de Danaus chrysippus (Linné) et d'Hypolimnas misippus (Lépidoptères Rhopalocères) en Afrique et en Asie. C. R. Soc. Biogéogr., 486, 179-187.

POUlton, E. B. 1908. Essays on Evolution 1889-1907. Clarendon Press, Oxford.

PUNNETT, R. C. 1915. Mimicry in Butterflies. Cambridge University Press, Cambridge.

SMITH, D. A. s. 1975. Genetics of some polymorphic forms of the African butterfly Danaus chrysippus. Ent. Scand., 6, 134-144.

SMITH, D. A. S. 1976. Phenotypic diversity, mimicry and natural selection in the African butterfly Hypolimnas misippus L. (Lepidoptera: Nymphalidae). Biol. J. Linn. Soc., 8, 183-204.

SMITH, D. A. S. 1984. Mate selection in butterflies: competition, coyness, choice and chauvinism. In: VaneWright, R. I. and Ackery, P. R. (eds) The Biology of Butterflies, pp. 225-244. Symposia of the Royal Entomological Society of London no. 11. Academic Press, London.

SMITH, D. A. S. AND GORDON, I. J. 1987. The genetics of the polymorphic tropical butterfly Hypolimnas misippus: the classification of phenotypes and the inheritance of forms misippus and inaria. Heredity, 59, 467-475.

southwood, T. R. E. 1981. Bionomic strategies and population parameters. In: May, R. M. (ed.) Theoretical Ecology: Principles and Applications, 2nd edn., pp. 30-52. Blackwell Scientific Publications, Oxford.

STEARns, s. C. 1992. The Evolution of Life Histories. Oxford University Press, Oxford.

STRIDE, G. O. 1956. On the courtship behaviour of Hypolimnas misippus, with notes on the mimetic association with Danaus chrysippus. Br. J. Anim. Behav., 4, 52-68.

STRIDE, G. O. 1957. Investigations into the courtship behaviour of Hypolimnas misippus L. (Lepidoptera, Nymphalidae), with special reference to the role of visual stimuli. Br. J. Anim. Behav., 5, 153-167.

TURNER, J. R. G. 1983. 'The hypothesis that explains mimetic resemblance explains evolution': the gradualistsaltationist schism. In: Greene, M. (ed.) Dimensions of Darwinism, pp. 129-169. Cambridge University Press, Cambridge.

UnAmBA, J. A. 1968. Ecological Genetics of the Butterfly Hypolimnas misippus. Ph.D. Thesis, University of Sierra Leone, Freetown.

wilbur, H. M. 1977. Propagule size, number and dispersion pattern in Amblyostoma and Asclepias. Am. Nat., 111, 43-68. 